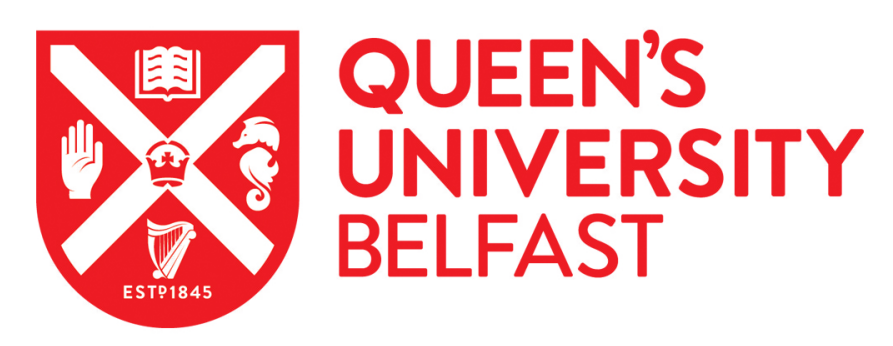

\title{
Contract-Based Knowledge Protection and Cooperation Performance
}

Wang, L., Wang, L., \& Zhang, M. (2020). Contract-Based Knowledge Protection and Cooperation Performance. Paper presented at 80th Annual Meeting of the Academy of Management.

\section{Document Version:}

Peer reviewed version

Queen's University Belfast - Research Portal:

Link to publication record in Queen's University Belfast Research Portal

Publisher rights

Copyright 2020 The Author.

\section{General rights}

Copyright for the publications made accessible via the Queen's University Belfast Research Portal is retained by the author(s) and / or other copyright owners and it is a condition of accessing these publications that users recognise and abide by the legal requirements associated with these rights.

Take down policy

The Research Portal is Queen's institutional repository that provides access to Queen's research output. Every effort has been made to ensure that content in the Research Portal does not infringe any person's rights, or applicable UK laws. If you discover content in the Research Portal that you believe breaches copyright or violates any law, please contact openaccess@qub.ac.uk. 


\title{
Contract-based knowledge protection and cooperation performance: The effects of technological turbulence and legal system completeness
}

\begin{abstract}
This study examines the direct effects of technological turbulence and legal system completeness on firm's contract-based knowledge protection and their moderating effects on the relationship between contract-based knowledge protection and cooperation performance. The model is tested using survey data collected from 227 manufacturing firms in China. It finds that technological turbulence and legal system completeness both have a significant and positive effect on contract-based knowledge protection. In addition, technological turbulence weakens the positive relationship between contract-based knowledge protection and cooperation performance, while legal system completeness strengthens the same relationship. The findings enrich our knowledge on how task and institutional environments are related to performance outcomes through shaping firm's behaviors and provides insight into firm's knowledge protection measures in cooperation.
\end{abstract}

KEY WORDS contract-based knowledge protection, technological turbulence, legal system completeness, cooperation performance

\section{Introduction}

While successful inter-firm cooperation is a critical source of competitive advantages and superior performance, firms always face the huge risk of knowledge leakage. Therefore, how to protect firm's private knowledge becomes an important governance problem in cooperation 
(Yang et al., 2014; Panico, 2017). This issue is even more salient in developing economies such as China. In the latest round of US-China Trade War, the US government accuses China of "IP theft" and "forced technology transfer", as stated in the report on Section 301 investigation of China. Despite China's considerable effort to improve, its intellectual property protection system is still weak due to the doubtful effectiveness of IPRs (Luo, 2005; Wang, Li, \& Chang, 2016). For example ${ }^{1}$, on October $28^{\text {th }}, 2019$, Apple's latest wireless headset AirPods Pro met with consumers for the first time, while a digital products supplier in Huaqiang-North, a commercial area in Shenzhen, revealed that the first cheap copy could be shipped as soon as November $5^{\text {th }}$. It is no doubt that Apple has patented its products, while a huge risk of knowledge leakage and value appropriation is still inevitable in such environment where intellectual property rights (IPRs) could hardly be efficacious as expectantly. Thus, it becomes a crucial issue that what measures, in addition to IPRs, should firms take to effectively protect their knowledge when they do business in China, and how would the unique environment characteristics of China affect firm's knowledge protection behavior and its value.

In fact, firms in China have always faced a highly uncertain task environment and a relatively imperfect institutional environment, which would affect firm's governance decisions and the value of governance mechanisms (Wang et al., 2016). For example, due to lack of sufficient resources and external capital market support, firms in developing countries face greater challenges of technological turbulence from global competition (Jean et al., 2014; Wu, Liu, \& Zhang, 2017). Meanwhile, there are lots of inadequacies and changes in formal institutional environment (Yang et al., 2018), especially the incomplete legal system (Luo, 2005;

\footnotetext{
${ }^{1}$ More detail, see https://www.jiemian.com/article/3647683.html
} 
Wang, Lin, \& Zhou, 2019). Thus, a high level of technological turbulence and low level of legal system completeness are two critical characteristics of task environment and institutional environment in developing economies such as China. It is not entirely clear that how would these unique environment characteristics of China affect firm's knowledge protection behavior.

The knowledge protection literature has long focused on IPRs, such as patents, copyrights, trademarks (Candelin-Palmqvist, Birgitta, \& Ulla-Maija, 2012). However, these property rights-based approaches have limitations, such like the considerable cost and narrow protection scope, which highlight the importance to explore broader knowledge protection mechanisms (Wadhwa, Bodas Freitas, \& Sarkar, 2017; Gast et al., 2019). Perhaps more importantly, most developing countries have yet established effective legal laws and regulations about IPRs. Some studies have realized that contract-based knowledge protection is also an important approach adopted extensively by firms to secure appropriability in inter-firm cooperation (Schubert, 2016; Veer, Lorenz, \& Blind, 2016; Stefan \& Bengtsson, 2017). Firm can use contracts to clearly stipulate the scope and depth of knowledge sharing, explicitly presuppose some knowledge isolating measures, establish formal information exchange channels and conform the use and protection of knowledge to contracts (Norman, 2001; Mayer, 2006; Müller, 2010; Schubert, 2016).

Although contract-based knowledge protection is of great significance in cooperation governance, there are still some gaps need to be addressed. First, comparing with the exhaustive research on IPRs, there are insufficient empirical studies devoted to the specifically role of contract-based knowledge protection. As mentioned above, considering the inherent limitations of IPRs, exploring diverse organization isolation mechanisms can help firm protect its private 
knowledge thoroughly (Wadhaw et al., 2017) and thus provide a holistic view of knowledge protection in inter-firm cooperation. Second, we know little about how environment factors would affect this knowledge protection approach and its value in cooperation governance. Though the literature has explored firm-level or transaction-level antecedents of firm's knowledge protection behaviors, such as firm size, relationship capital (e.g. Neuhäusler, 2012; Norman, 2004), how external environment factors influence firm's knowledge protection behaviors in alliance has received little attention. Moreover, considering the inconsistent understanding of the relationship between knowledge protection and cooperation performance, researchers have proposed that context may influence the effects and value of knowledge protection (e.g. Jean, Sinkovics, \& Hiebaum, 2014; Wei, Du, \& Bao, 2018). However, the relevant contextual factors have not been adequately explored, especially external environment factors. Therefore, combined with the environment characteristics of China, this paper will investigate how technological turbulence and legal system completeness affect firm's contractbased knowledge protection in cooperation and further the cooperation performance to address the mentioned gaps.

More specifically, we develop a framework (see Figure 1) to examine the effects of technological turbulence and legal system completeness on contract-based knowledge protection. We first consider how technological turbulence and legal system completeness affect contract-based knowledge protection. We further examine the moderating roles of technological turbulence and legal system completeness on the relationship between contractbased knowledge protection and cooperation performance. By doing these, this study has the following contributions. First, this paper enriches the research on alliance knowledge protection 
by exploring contract-based knowledge protection in cooperation based on the developing economy's context. Second, by demonstrating the effects of technological turbulence and legal system completeness, we extend the research on the antecedents of contract-based knowledge protection (e.g. Norman, 2004; Neuhäusler, 2012; Yang et al., 2014) and help to provide a holistic view of knowledge protection. Third, it also enriches the understanding of the relationship between knowledge protection and performance outcomes (e.g. Jean et al., 2014; Wei et al., 2018) by exploring the moderating roles of task and institutional environments. Taken together, this study also responds to scholars' discussion on how macro environmental factors are related to performance outcomes through shaping firm's behaviors (e.g. Chang, Bai, \& Li, 2015; Sheng et al., 2018).

\section{Literature review}

\subsection{Contract-based knowledge protection}

Inter-firm cooperation is an important access for firm to external knowledge, technology and other resources, but also exposes firm to the risk of knowledge leakage (Frishammar, Ericsson, \& Patel, 2015). Even in the partnership, uncontrolled knowledge transfer tends to increase the bargaining power of partner or create a future competitor for the original knowledge owner (Baughn et al., 1997; Jiang et al., 2013). Firms need to establish a series of knowledge protection mechanisms to avoid their key knowledge being imitated and appropriated by partners and reduce the risk and cost of knowledge leakage in cooperation. Therefore, knowledge protection becomes the important content of inter-firm relationship governance (Jiang et al., 2013; Hoffmann et al., 2018; Gast et al., 2019).

In particular, contract-based knowledge protection has gradually attracted the attention of 
scholars in recent years. Norman (2001) pointed out that the alliance partners can protect their knowledge through contracts to stipulate the scope of knowledge exchange, presuppose some protection measures, and establish formal information exchange channels. Mayer (2006) pointed out that contracts can be used to help realize more knowledge benefits from cooperation rather than create spillovers, as a more detailed contract can help the parties align their expectation and reduce the risk of misunderstanding and opportunism. Schubert (2016) considered that contracts can contain clauses on the mutually accepted use of tacit knowledge and know-how, flexibly adapting to partner needs and reducing the risk of knowledge infringement. Wei et al. (2018) pointed out that clients commonly resort to legal contracts as an effective mechanism in protecting proprietary knowledge as contacts can detail task descriptions, spell out customer-specific or reusable project components, and allocate intellectual property when new knowledge is created during collaboration. Based on these discussions and the prior literature, this study defines contract-based knowledge protection as an mechanism to avoid the knowledge leakage to partners, which resort to cooperative contracts to stipulate the scope of knowledge exchange and behaviors of both cooperative parties, presuppose knowledge isolating measures, and establish formal information exchange channels (Norman, 2001; Mayer, 2006; Müller, 2010; Schubert, 2016; Wei et al., 2018).

Although contract-based knowledge protection may be naturally linked to formal contracts or IPRs, we cannot equate contract-based knowledge protection with them. Formal contracts involve various issues of cooperation and are not completely used with for knowledge protection, while contract-based knowledge protection is an approach based on the design and use of formal contracts to protect knowledge exclusively. And IPRs grant the right to exclude 
any other party from using protected intellectual property, while contract-based knowledge protection only binds parties who agree to the relevant contracts (Schubert, 2016). More importantly, given the certain limitations of IPRs, contract-based knowledge protection is an important and necessary alternative or complement. It is undeniable that IPRs cannot cover all types of knowledge, such as unpatented knowledge, tacit knowledge, and new knowledge creating in cooperation (Olander, Vanhala, \& Hurmelinna-Laukkanen, 2014; Perri \& Andersson, 2014). While contract-based knowledge protection could play a better role in protecting these knowledge especially tacit knowledge (Manhart \& Thalmann, 2015). Contract-based knowledge protection provides basic rules and norms for knowledge exchange in cooperation and thus avoids unnecessary social interaction between interface employees, while the transfer of tacit knowledge exactly requires adequate social interaction (Norman, 2001; Olander et al., 2011; Manhart \& Thalmann, 2015; Schubert, 2016). Moreover, contract-based knowledge protection can be more flexibly adapted to the different partnerships' needs according to the design and implementation of specific contracts and thus might play a better protective effect than IPRs (Schubert, 2016).

\subsection{Task environment and institutional environment}

Because inter-organizational relationships are embedded in the larger social context, the choice and effect of governance mechanisms are influenced by contextual factors, including task and institutional environments (Child, Chung, \& Davies, 2003; North, 2005; Wang et al, 2016). Task environment is the external condition that affects the organization's internal behavior and functioning of firm (Dess \& Beard, 1984; Srivastava \& Frankwick, 2011). One major aspect of task environment is technological turbulence which defined as "the rate of technological change 
in the industry" (Kohli \& Jaworski, 1990), and is believed to influence firm's governance decisions and determine the value of various governance structures (Dess \& Beard, 1984; Claussen, Kretschmer, \& Stieglitz, 2015; Qian, Yang, \& Li, 2016), such as the formation of alliances (Hagedoorn, 1993), the effects of contract governance (Lee and Cavusgil, 2006) and "guanxi" (Gu, Hung, and Tse, 2008).

Although these studies provide some helpful insights, few studies have discussed the impact of technological turbulence on firm's knowledge protection. On the one hand, technological turbulence strongly impacts the value of a firm's knowledge resources (Su et al., 2016), which may determine the motivation of knowledge protection. On the other hand, technological turbulence raises the adaptive requirements for strategic flexibility of firms to cope with the challenges triggered by technological turbulence (Shu, Jin, \& Zhou, 2017) and highlight business ties to acquire the latest market information such as technology changes and technical resource (Sheng et al., 2011). As a result, it may change the matching between knowledge protection mechanism and firm's strategic needs and shape the effect of knowledge protection on performance outcomes. Contract-based knowledge protection, as a formal appropriability mechanism, can protect new and immature technical knowledge more effectively (Schubert, 2016), and thus might better meet the need of knowledge protection under technological turbulence. However, contract-based knowledge protection may hamper knowledge exchange and damage mutual trust in cooperation (Jean et al., 2016; Wei et al., 2018), which is not in accordance with strategic flexibility and thus damages the ability of firm to cope with technological turbulence and to seek for better performance outcomes. Therefore, technological turbulence might not only determine firm's motivation to adopt contract-based 
knowledge protection, but also moderate the relationship between contract-based knowledge protection and cooperation performance.

Institutional environment might also affect the value of governance mechanism since it determines the transaction costs of economic exchange (North, 2005; Peng et al., 2008; Wang et al., 2016). The institution is often referred to as the "rule of game" (North, 1990). Institutional theory holds that organizational behaviors and strategic choices are significantly influenced and constrained by institutional forces (Scott, 2001; North, 2005; Peng, 2008; Chang et al., 2015; Yang et al., 2018). When organization's behavior is inconsistent with the institutional order, the institutional force will increase organization's various costs, including "economic costs (increasing risk), cognitive costs (requiring more thought) and social costs (reducing legitimacy) " (Peng et al., 2009; Li et al., 2010).

In developing economies, legal system incompleteness is one of the most important institutional factors. Contract-based knowledge protection is based on contract governance mechanism, of which the underlying assumption is the existence of an effective legal system to protect firm's interests and coordinate joint actions (Shou, Zheng, \& Zhou, 2016). Compared with developed economies, there are certain limitations and costs to managing partnerships through contracts due to the incompleteness of legal system in developing economies (Shou et al., 2016; Zhou et al., 2016; Yang, 2018). However, many developing economies, such as China, are striving to improve their laws and regulations and promote legal system reform (Yang et al., 2018). Therefore, with the improvement of legal system, the costs of adopting contract-based knowledge protection approach to manage knowledge risk in cooperation will be accordingly reduced. Additionally, the effectiveness of inter-firm governance mechanisms depends on their 
alignment with external institutional environment (Wang et al., 2016). With the improvement of legal system, contract-based knowledge protection is more consistent with the pressure of institutional environment, which may play a better control role in curbing opportunistic behaviors associated with knowledge and promoting cooperation performance. Thus legal system completeness might also both affect contract-based knowledge protection and its effect on cooperation.

Briefly, we believe that the effects of firm's governance decisions and activities associated with knowledge protection are influenced by task and institutional environments. This study will focus on technological turbulence in task environment and legal system completeness in institutional environment, and explore the direct impact and contextual role of the two external environment factors on contract-based knowledge protection. More formally, technological turbulence refers to the total amount and unpredictability of product or service technology changes in the industry (Slater \& Narver, 1994); legal system completeness refers to the degree of completeness of the formal legal system related to business operations, including the laws and regulations concerning corporate's intellectual property rights, ownership, contracts, etc. (Luo, 2005; White et al., 2015; Wei et al., 2017).

\section{Hypothesis development}

\subsection{The effect of technological turbulence and legal system completeness on contract- based knowledge protection}

Technological turbulence reflects the speed of technological change within the industry (Jaworski \& Kohli, 1993). We predict that with higher technological turbulence, firm is more likely to adopt contract-based knowledge protection. 
First, with high technological turbulence, the value and importance of firm's knowledge are enhanced, which promote firm's motivation to implement contract-based knowledge protection. As a strategic resource, firm's knowledge is one of the dominant sources of competitive advantage in turbulent technological environment (Sheng et al., 2011). Therefore, firms will be more motivated to protect their knowledge and maintain the exclusivity in order to sustain the competitive advantage when technological turbulence is high. Additionally, technological turbulence strongly influences the value of firm resources, especially enhancing the value new knowledge (Zhou, 2006; Su et al., 2016). Therefore, as technological turbulence increases, a firm will be more motivated to protect the new knowledge because the value and importance of this knowledge will accordingly increase (Norman, 2002; Perri \& Andesson, 2014). In particular, contract-based knowledge protection provides a suitable alternative, which can limit the unintended flow of knowledge between firms, no matter whether the knowledge has been patented or not, and thus play an effective role in protecting firm's important knowledge, especially technical inventions (Schubert, 2016). As a result, firm could be more motivated to adopt contract-based knowledge protection when technological turbulence is high.

Second, when technological turbulence is high, firm would be more likely to use contractbased knowledge protection because of the concern for isolating its sensitive knowledge from different partners. A high rate of technology change provides imitators with ways to cope and improve existing products, neutralizing the technology leadership advantage enjoyed by innovators (Zhou, 2006; Yeung et al., 2013). Therefore, once the important knowledge of a firm is lost to competitors and applied to competitive products, the competitive advantage and industry position of the firm will be challenged. In the case of inter-firm cooperation, it is at 
high risk to leak some important knowledge to partner unknowingly, because it will strengthen the bargaining power of the partner or create a potential competitor in future (Baughn et al., 1997; Jiang et al., 2013; Frishammar et al., 2015). Considering the distinguished knowledge base and structure of different partners, with the increase of technological turbulence, firms need to strengthen their knowledge protection for different partnerships through customized approaches, of which contract-based knowledge protection is an effective means. In particular, contract-based knowledge protection can clearly stipulate distinguishing scopes of knowledge exchange for the needs of different partnerships according to the specific contracts. Thus, in order to isolate sensitive knowledge from different partners, firm would be more likely to implement more contract-based knowledge protection when technological turbulence is high.

Third, when technological turbulence is high, firm would be more motivated to use contract-based knowledge protection to keep up with the changes in knowledge protection content. As technology turbulence increases, the key technology of a certain industry changes and updates faster (Jaworski \& Kohli, 1993). As a result, firm's sensitive knowledge correspondingly changes, which urges firm to adjust the scope of protected knowledge in a timely manner. Additionally, firms also need to protect some new and developing knowledge that could cope with technological turbulence. Contract-based knowledge protection can flexibly adapt to the changes of technology through negotiable contract terms which stipulate the scope of knowledge exchange and the processes of knowledge protection (Norman, 2001; Mayer, 2006; Schubert, 2016). Therefore, as technological turbulence increases, contract-based knowledge protection is much needed for firm to meet dynamic need of knowledge protection. Combined with the above analyses, this study suggests that a high level of technological 
turbulence enhances the value and importance of firm's knowledge, strengthens the need to distinctively isolate knowledge from different partners and the need to adjust the protection scope with technology change, which promote firm's motivation to use contract-based knowledge protection. That is,

H1. There is a significant positive relationship between technological turbulence and contract-based knowledge protection.

According to institution theory, the institutions create the rules of the game and regulate business activities through formal and informal constraints, of which legal system is enacted as a principal formal constraint (North, 1990). The strength of legal system, especially in the protection of firm's intellectual property rights and ownership benefits, affects the costs of transactions, information scanning and operational monitoring (Luo, 2005). We argue that with a high level of legal system completeness, firm is more likely to adopt contract-based knowledge protection in cooperation.

First, with a more complete legal system, firm will be more likely to use contract-based knowledge protection because the lower economic costs. The legal system is the basis for the formulation and implementation of contracts (Bai, Sheng, \& Li, 2016). On the one hand, legal system provides a sufficient reference standard for firm's formal contract governance and knowledge protection. Through a complete legal system, firm and its partner can spend less cost and are easier to develop reliable and precise contract terms to protect both parties' knowledge (Peng, 2003; Luo, 2005; Bai et al., 2016). On the other hand, the strength of the legal system determines the credibility of committing the contractual obligations and the relatively efficiency of contractual provisions in coordinating exchange relationships. With the 
improvement of legal system completeness, the validity and enforceability of formal contracts become stronger (North, 1990; Li et al., 2010) and thus contract-based knowledge protection will be more effective and get lower economic costs to implement this approach.

Second, when the legal system is more complete, the managers can implement contractbased knowledge protection more easily by lowering cognitive costs. The complete legal system, which provides clear rules, regulations, and formal standards (Wei et al., 2017), can guide and help firm to use cooperative contracts to protect knowledge, and thus leads to lower cognitive costs for firm. On the contrary, considering that under-developed legal systems are generally ambiguous, contested, and riddled with loopholes, it is a burden for firms to comprehend an abstract and cumbersome legal system (Roy \& Oliver, 2009; Wang, Jin, \& Zhou, 2019). In such case, it is difficult for firm to effectively implement contract-based knowledge protection, because the incomplete of legal system consumes valuable resources and attention by increasing the transactional costs of the communication and coordination (Luo, 2007; Wang et al., 2019).

Third, a more complete legal system give firm more confidence to use contract-based knowledge protection as the increase in legitimacy and the decrease in social costs. Complete legal system makes the market rules more clear. As a result, a rule-based, impersonal exchange regime will become the norm for conducting business (Peng, 2003; Bai et al., 2016), which legitimizes the use of contract-based knowledge protection. On the contrary, if the legal system is incomplete and correspondingly the enforcement of contract is weak, firms need to rely on informal relationship governance mechanisms to manage cooperation (Peng, 2003; Cao \& Lumineau, 2015; Yang et al., 2018). However, contract-based knowledge protection is 
inconsistent with some relationship norms such as trust and is more difficult to obtain the recognition of partners and social legitimacy, which may lead to the defensive attitudes and reactance of partners (Bai et al., 2016; Wang et al., 2016; Yang et al., 2018). Therefore, the improvement of legal system makes the contract-based knowledge protection more easily recognized by partners and thus the social costs become lower.

In summary, with a high level of legal system completeness, contract-based knowledge protection will bring lower economic costs, cognitive costs and social costs, get higher legitimacy and better protection effect, therefore, firm will be more likely to adopt the contractbased knowledge protection. Thus, we propose the following:

H2. There is a significant positive relationship between legal system completeness and contract-based knowledge protection.

\subsection{Contract-based knowledge protection and cooperation performance}

In essence, the improvement of cooperation performance is derived from promoting both parties' cooperative behaviors that increase the efficiency and the creativity of their actions (Villena, Revilla, \& Choi, 2011; Christoffersen, Plenborg, \& Robson, 2014). We anticipate that, overall, contract-based knowledge protection has a positive effect on cooperation performance.

First, contract-based knowledge protection reduces the risk and costs of knowledge leakage in cooperation. From the perspective of TCE, the risk of knowledge spillover in interfirm cooperation increases the costs of transaction (Mayer, 2006; Li et al, 2008; Jiang et al., 2013; Jiang et al., 2016). As a result, firms will consider knowledge protection in the governance decisions of existing exchange relationships to avoid the costs of such spillover (Mayer, 2006; Li et al, 2008; Manhart \& Thalmann, 2015). Contract-based knowledge 
protection can prevent the leakage of firm's sensitive knowledge to partner by stipulating the details of knowledge exchange and protection, and establishing formal communication channels (Norman, 2004; Mayer, 2006; Schubert, 2016). By contract-based knowledge protection, firm would achieve relatively better cooperation performance with lower risk and costs of unwanted knowledge spillover in cooperation.

Second, contract-based knowledge protection provides a rational trust foundation for cooperation by preventing the risk of knowledge leakage, and enhances the efficiency and depth of cooperation. For focal firm, contract-based knowledge protection regulates the knowledge exchange behaviors, guarantees the knowledge security during cooperation, and frees resources to invest in cooperation without worrying the unintentional leakage of knowledge. For partner, the contract terms associated with knowledge protection are agreed with and signed in advance, and thus can lessen the misunderstanding and opportunism of the partner and make partner more engaged in cooperation (Mayer, 2006). Therefore, contract-based knowledge protection can make both parties trust each other and engage more in active cooperative actions, improve the efficiency of cooperative resource utilization, and finally promote cooperation performance (Mayer, 2006; Lee et al., 2007; Wei et al., 2017).

However, some studies have pointed out that knowledge protection may have a negative impact on cooperation performance. For example, firm's knowledge protection may signal distrust and hinder communication and interaction between partners, which may reduce the collaborative relationship quality and cooperation performance (Wei et al., 2017). However, in the context of emerging economies, the legal system, including intellectual property law, is still not adequately perfect, and there are still many unfair competitions in the market (Peng, 2003; 
Chang et al., 2015; Wang et al., 2019). Once the key knowledge of the firm is leaked or stolen, it is likely that plagiarism and cheap copy will occur immediately and cannot get effective legal sanctions. Therefore, in the emerging economies, knowledge protection is more important in preventing knowledge leakage risks in cooperation to serve as a means to overcoming institutional voids, of which the benefits may outweigh its deficiencies (Jean et al., 2014). Therefore, we propose:

H3: There is a significant positive relationship between contract-based knowledge protection and cooperation performance.

\subsection{The moderate effects of technological turbulence and legal system completeness}

As discussed above, we posit that technological turbulence and legal system completeness not only have direct effects on the contract-based knowledge protection, but also can moderate the relationship between contract-based knowledge protection and cooperation performance.

We propose that technological turbulence will weaken the positive relationship between contract-based knowledge protection and cooperation performance. When the technological turbulence is high, firms need to quickly adjust their operations and actions and continuously create and apply new knowledge to cope with rapid changes of technology (Su et al., 2016). At this case, in order to better cope with the technological turbulence, firms should maintain good cooperative relations with partners and strengthen collaborative coordination and firm's strategic flexibility (Paulraj \& Chen, 2007; Terawatanavong et al., 2011). In this case, firms need to not only establish and protect their own knowledge resources, but also establish close and flexible cooperation with partners to keep strategic flexibility. However, contract-based knowledge protection fixes the scope of knowledge exchange and the formal communication 
channels through the form of formal contracts, and firm and its partner must carry out the activities in a defined manner, which reduce the flexibility of knowledge exchange and impede the process of new knowledge creation (Norman, 2004; Arora et al., 2016). Moreover both knowledge protection and formal contracts signal a distrust in partner (Wei et al., 2017; Zhang, Li, \& Huang, 2017), and thus make it difficult to establish a more flexible and closer cooperative relation to cope with technological changes. Therefore, the positive effect of contract-based knowledge protection on cooperation performance has declined in high technological turbulence.

On the contrary, with low technological turbulence, firms have lower need and motivation to cope with technological changes by establishing close cooperative relations with partners. With fewer opportunities when technological turbulence is low, it is less significant for firm to seize the opportunities through inter-firm collaboration ( $\mathrm{Su}$ et al., 2016). Contract-based knowledge protection will plays a more positive role in performance outcomes because protecting important knowledge of firm and maintaining competitive advantages is more important than seize the technological opportunities in this situation. Therefore, a low turbulent technological environment would weaken the negative impact of contract-based knowledge protection and relatively strengthen the positive relationship between contract-based knowledge protection and cooperation performance.

Taken together, though contract-based knowledge protection can protect important knowledge and establish basic rational trust, in the context of high technological turbulence, it hampers knowledge exchange, enlarges the signal of distrust, and thus is detrimental to the strategic flexibility and the new knowledge creation in order to cope with technological changes. 
Therefore, the positive relationship between contract-based knowledge protection and cooperation performance would be declined in high technological turbulence. That is:

H4: Technological turbulence weakens the positive relationship between contract-based knowledge protection and cooperation performance.

We propose that legal system completeness will strengthen the positive relationship between contract-based knowledge protection and cooperation performance. A complete legal system improves the legitimacy of the contract use and imposes regulatory pressure on both parties to aside by the terms and conditions stipulated (Bai et al., 2016). Therefore, if both parties get an agreement on knowledge protection, the formal institutional pressure of legal system will force them to hardly violate the contractual provisions and avoid knowledge appropriation (Greif, 2005). Furthermore, a complete legal system can also reduce ambiguity in contract enforcement and inhibit opportunistic behaviors and conflicts (Bai et al., 2016). Therefore, with a relatively complete legal system, firm can better deal with the risk of knowledge leakage under unexpected situations by the using of contract-based knowledge protection, which is more conducive to guarantee cooperation performance. Therefore, when legal system is more complete, contract-based knowledge protection has lower enforcement costs and stronger effectiveness, which can better deal with knowledge appropriation risk in cooperation, and thus have a more positive effect on cooperation performance.

On the contrary, when legal system is relatively incomplete, the formal laws and regulations protecting the interests of firm and intellectual property rights are relatively inadequate or poorly enforced. It is difficult or expensive for firms to follow legal procedures to protect business interests and enforce contracts in such case, which increasing transaction 
risk and costs (Wang, Zhang, \& Li, 2017). A heightened perception of opportunism and distrust engendered by legal system incompleteness increases the resources required by both parties to monitor each other's behavior (Wang et al., 2019). Therefore, with a lower level of legal system completeness, contract-based knowledge protection is more costly to enforce and more difficult to deal with the exchange hazard associated with knowledge leakage, which will weaken the positive effect on cooperation performance. Therefore, we propose:

H5: Legal system completeness strengthens the positive relationship between contractbased knowledge protection and cooperation performance.

[Insert Fig.1 here]

\section{Research method}

\subsection{Sampling and data collection}

To test our hypotheses, we used survey data collected from manufacturing firms in China. China offers an ideal context for studying the influence of macro-environment factors on firm's knowledge protection and performance outcomes, because its task environment and institutional environment vary significantly by regions and industries within the country. Meanwhile, China is one of the fastest-growing emerging economies in the world, and Chinese firms are increasingly focusing on innovation and collaborative R\&D (Wei et al., 2017; Sun et al., 2017). However, despite the rapid economic growth in China, the legal systems, especially intellectual property protection, are not yet adequately developed (Luo, 2005; Wang et al., 2019), and the firms often perceive varying degrees of legal system completeness and efficiency across 
regions and industries (Zhou \& Poppo, 2010).

Before the survey instrument was developed, we conducted ten in-depth interviews with senior executives of manufacturing firms to explore firm's knowledge management practices in cooperation and their perceptions of task environment and institutional environment. Consistent with our theoretical predictions, these interviews indicate that contract-based knowledge protection approaches are often adopted by firms in cooperation, and the firms perceive varying task and institutional environments. Based on the findings of these interviews and literature review, we developed the English version of the survey, translated it into Chinese, and then translated it back into English. Translation and back-translation were performed by two independent scholars to ensure conceptual accuracy and equivalence. After that, we contacted a pilot test with 20 manufacturing firms in China. We invited their senior executives to fully complete the questionnaire and give feedback about the issues and suggestions on the questionnaire. Based on the feedback, we finally revised and refined the questionnaire.

According to the Bureau of Commerce, we obtained a company directory for four representative economic regions and randomly selected 500 manufacturing firms that represent diverse geographic, economic and demographic conditions in China. We first contacted these firms by telephone, explained the purpose of the study, and promised confidentiality and feedback reports in order to solicit their cooperation. For the reliability of the questionnaire survey, we collected the data through face-to-face interviews with the senior executives of the interviewed firms who actually know the knowledge management activities and performance outcomes of cooperation. Finally, we successfully obtained 227 usable questionnaires with a response rate of $45.4 \%$, after dropping non-response samples and samples with excessive 
missing values. The informants' positions included the chairman, CEO or general manager, vice general manager, department manager and other senior managers familiar with cooperation matters, most of whom have served in current position for more than 3 years $(86.2 \%)$. The partner firms are focal firms' suppliers $(38.1 \%)$, customers $(49.1 \%)$, or R\&D partners $(23.8 \%)$. The duration of the inter-firm partnership is mostly more than 3 years $(85.4 \%)$. The sample covered various manufacturing industries and most provinces in the country and a more detailed description of the sample is shown in Table 1.

We used MANOVA to assess the likelihood of non-response bias by splitting the total sample into early and late respondents (Armstrong \& Overton, 1977). The comparison results showed no significant differences in term of firm characteristics (i.e., firm size, industry type, firm ownership), indicating that non-response bias is not a serious concern in this study.

[Insert Table 1 here]

\subsection{Measures}

We present the measurement scales and their validity assessment in Appendix A. The measurements of the constructs in this study are based on the existing literature and all use the Liket5 point scale. The measure of legal system completeness was developed from Luo (2005) and White et al. (2015), used to assess the extent to which managers perceive completeness of laws and regulations influencing the operations and cooperation of firms. We adapted the scales of technological turbulence from Terawatanavong (2011), who assessed the extent to which magnitude of changes and breakthrough in technology. The measure of contract-based 
knowledge protection is developed from Norman (2001) and Müller (2010), assessed the degree to which firm uses cooperative contracts as a knowledge protection approach.

We based our subjective cooperation performance measure on Musarra et al. (2016) and Schilke and Lumineau (2018), assessed the utilization efficiency of cooperative resources, the efficiency of input-output transformation, and the extent of cooperation goals accomplishment. Although qualitative financial indicators can be also used to measure cooperation performance, it is difficult to quantitatively reflect and separate the benefits accruing from cooperation (Muthusamy \& White, 2006; Walter, Lechner, Kellermanns, 2008). Therefore, we measured cooperation performance from the perspective of focal firm that reflect the strategic benefits of the specific partnership and the accomplishment of cooperation objectives.

Controls. This study used firm size (number of employees), firm age, industry, cooperation duration, and transaction-special investment as the control variables in the analysis. The characteristics of the firm, its industry and partnership will influence the inter-firm relationship governance and cooperation performance. Firms of different sizes have different resources and power, which may determine the selection of knowledge protection approaches (Olander et al., 2011; Olander et al., 2014). Firm age is included because older firms may have more experience and have established more capabilities to handle and benefit from partnerships (de Leeuw, Lokshin, \& Duysters, 2014). Different structures and characteristics between different industries will also bring about the industry effects influencing partnerships and performance outcomes (Muthusamy \& White, 2006). Additionally, the appropriability regime and the key knowledge are different in different industries (Teece, 1986). Norman (2004) suggested that the cooperation experiences of focal firm and its partner may reduce the extent of their knowledge 
protection. Long cooperation duration gives firm more cooperation experiences, which may shape firms knowledge protection decisions. Transaction-specific investments are the investments that firms use to tailor their partners and are highly specific and continual (Liu, Luo, \& Liu, 2009). Transaction-special investments have an effect on opportunistic risks and interdependencies in the partnership, which in turn will influence firm's governance decisions and cooperation performance (Liu et al., 2009; Zhou \& Poppo, 2010). We used the natural logarithm of the number of employees in the firm, the establishment time of the firm, the establishment time of cooperation to measure firm size, firm age, and cooperation duration separately, and used three dummy variables to represent the industry classification of firm. The measure of transaction-special investment was adapted from Zhou and Poppo (2010), using four items to measure the various inputs or changes of the firm to partner specifically.

\subsection{Construct validity}

To assess the reliability and validity of the construct, we conducted a confirmatory factor analysis. The measurement model fit well for the sample, in which each questionnaire item was only loaded on its respective potential construct and covariance coefficients among potential constructs were free $\left(\chi^{2}{ }_{(125)}=230.998\right.$, comparative fit index $[\mathrm{CFI}]=0.954$, Tucker-Lewis index $[\mathrm{TLI}]=0.944$, root mean squared error of approximation $[\mathrm{RMSEA}]=0.061$, standardized root mean square residual $[\mathrm{SRMR}]=0.0507)$. As shown in Appendix A, all factor loadings were significant $(\mathrm{p}<0.001)$. The Cronbach's $\alpha$ of each construct was greater than 0.700 , the composite reliability of each latent variable was greater than 0.800 , and the average variance extracted (AVE) of each construct exceeded 0.500. Furthermore, AVE of each construct was greater than the square of its respective construct's correlations coefficient with other constructs, 
indicating discriminant validity. Overall, these results collectively indicated the adequate reliability and validity of the measures. Table 2 presents the descriptive statistics and correlations of the variables.

\subsection{Common method bias}

Considering the potential concern of common method bias, the "MV" marker method was used to assess the severity of potential common method bias (Lindell \& Whitney, 2001). A variable that is theoretically unrelated to the substantive variables in the model is often used as "MV" marker to proxy the effect of common method bias (Lindell \& Whitney, 2001; Williams, Hartman, \& Cavazotte, 2010). In our survey, we also measured the government intervention, which refers to the degree of government intervention on firm's business operations. The measure items were adapted from Child et al. (2003) and Chang et al. (2015). This study used government intervention as the "MV" marker, and the smallest non-negative correlation between the MV and other variables was used to adjust the correlation $(r=0.012$, correlation between government intervention and cooperation duration). As shown in Table 2, the adjusted correlation did not change from significant to non-significant, indicating that the common method bias is not a serious concern in this study.

[Insert Table 2 here]

\section{Analyses and results}

This study used hierarchical regression analysis to test the hypotheses. The regression results are shown in Table 3. Considering the moderating effects in the model, we mean-centered the 
variables involved in the interaction terms to mitigate the potential multicollinearity threat (Aiken \& West, 1991). The variance inflation factors (VIFs) in the models are smaller than 2, indicating that multicollinearity is not a significant problem in the regressions. The dependent variable in Model 1-2 is contract-based knowledge protection. We entered control variables (Model 1) and independent variables (Model 2) sequentially into the regression. The dependent variable in Model 3-6 is cooperation performance. We entered control variables (Model 3), moderate variables (Model 4), independent variables (Model 5), and interaction items (Model 6) sequentially into the regression.

\subsection{Main effects of technological turbulence and legal system completeness}

Hypothesis $\mathrm{H} 1$ and $\mathrm{H} 2$ predict that technological turbulence and legal system completeness are positively related to contract-based knowledge protection. As shown in Table 3, Model 2, technological turbulence has a significant positive effect on contract-based knowledge protection $(\beta=0.186, \mathrm{p}<0.01)$. Similarly, legal system completeness has a significant positive effect on contract-based knowledge protection $(\beta=0.156, \mathrm{p}<0.05)$. H1 and $\mathrm{H} 2$ are supported respectively.

\subsection{Main effects of contract-based knowledge protection}

Hypothesis H3 predicts that there is a significant positive relationship between contract-based knowledge protection and cooperation performance. As shown in Table 3, Model 5, contractbased knowledge protection has a significant positive effect on firm cooperation performance $(\beta=0.300, \mathrm{p}<0.001)$. Furthermore, in Model 6, the positive effect of contract-based knowledge protection on firm cooperation performance is still significant $(\beta=0.280, \mathrm{p}<0.001)$, in support of H3. 


\subsection{Moderating effects of technological turbulence and legal system completeness}

Hypothesis $\mathrm{H} 4$ and $\mathrm{H} 5$ respectively predict that technological turbulence weakens the positive relationship between contract-based knowledge protection and cooperation performance, and legal system completeness strengthens the positive relationship between contract-based knowledge protection and cooperation performance. As shown in Table 3, Model 6, contractbased knowledge protection has a significant positive effect on cooperation performance $(\beta=0.280, \mathrm{p}<0.001)$, and the interaction effect between technological turbulence and contractbased knowledge protection is significant and negative $(\beta=-0.189, \mathrm{p}<0.01)$, supporting $\mathrm{H} 4$. While the interaction effect between legal system completeness and contract-based knowledge protection is significant and positive $(\beta=0.266, \mathrm{p}<0.001)$, in support of $\mathrm{H} 5$.

To facilitate interpretation, we plot the moderating effects in Fig. 2 to show how the relationship between contract-based knowledge protection and firm cooperation performance vary under the different conditions of high level and low level (higher/lower than one standard deviation) of technological turbulence and legal system completeness (Aiken \& West, 1991). Additionally, we also calculated the simple slopes and their statistical significance levels, according the low and high levels of the moderators (Aiken \& West, 1991).

As shown in Fig. 2, Panel A, when technological turbulence is low, contract-based knowledge protection has a significant positive effect on cooperation performance $(\beta=0.429$, $\mathrm{p}<0.001)$, but this effect is not significant when technological turbulence is high $(\beta=0.131$, $\mathrm{p}>0.05$ ). This result shows that technological turbulence weakens the relationship between contract-based knowledge protection and cooperation performance. Combined with the results from regressions, H4 is supported. Similarly, as shown in Fig. 2, Panel B, when legal system 
completeness is low, the effect of contract-based knowledge protection on cooperation performance is not significant $(\beta=0.069, \mathrm{p}>0.05)$, but when the degree of legal perfection is high, the effect becomes significant and positive $(\beta=0.491, \mathrm{p}<0.001)$. It shows that legal system completeness strengthens the positive relationship between contract-based knowledge protection and cooperation performance, supporting $\mathrm{H} 5$ further.

[Insert Table 3 here]

[Insert Fig.2 here]

\subsection{Additional Analysis}

Hypothesis $\mathrm{H} 1$ and $\mathrm{H} 2$ predict that technological turbulence and legal system completeness have a positive effect on contract-based knowledge protection respectively, and the regression result also supports $\mathrm{H} 1$ and $\mathrm{H} 2$, as shown in Table 3, Model 2. Therefore, when discussing the moderating role of technological turbulence and legal system completeness on the relationship between contract-based knowledge protection and cooperation performance, regression models may face endogenous concerns. According to Hamilton and Nickerson (2003), we used a threestage regression to correct for endogeneity. In Stage 1, we regressed contract-based knowledge protection on technological turbulence and legal system completeness. The regression showed that contract-based knowledge protection related positively to both technological turbulence $(\beta=0.179, \mathrm{p}<0.01)$ and legal system completeness $(\beta=0.157, \mathrm{p}<0.01)$. The results were 
consistent with our previous findings, indicating that it is necessary to use three-stage regression models to correct potential endogenity.

In Stage 2 and 3, we used residuals (observed values minus predicted values) as indicators of contract-based knowledge protection. Stage 2 regressed cooperation performance on contract-based knowledge protection, moderating variables (technological turbulence and legal system completeness), and control variables. In Stage 3, added the interaction terms. These results are shown in Table 3, Model 7 and 8, and contract-based knowledge protection still has a significant and positive effect on cooperation performance (Model 7, $\beta=0.300, \mathrm{p}<0.001$; Model 8, $\beta=0.268, \mathrm{p}<0.001$ ), again supporting H3. In Model 8, the interaction between technological turbulence and contract-based knowledge protection is significant and negative $(\beta=-0.197, \mathrm{p}<0.01)$, while the interaction between legal system completeness and contractbased knowledge protection is significant and positive $(\beta=0.270, \mathrm{p}<0.05)$, indicating that the positive relationship between contract-based knowledge protection and cooperation performance is weakened by technological turbulence and enhanced by legal system completeness respectively, in support of $\mathrm{H} 4$ and $\mathrm{H} 5$.

In order to further test the moderating effects, we use a median split to divide the sample to high- and low-moderator groups (Samaha, Palmatier, \& Dant, 2011; Ju \& Gao, 2017). Specifically, we split the data into high- and low-technological turbulence groups (observations above and below the median, respectively) and regressed cooperation performance on contractbased knowledge protection at both level. The results suggest that the effect of contract-based knowledge protection on cooperation performance is stronger in the low-technological turbulence group $(\beta=0.369, \mathrm{p}=0.000)$ than in the high-technological turbulence group $(\beta=0.192$, 
$\mathrm{p}=0.027)$, and the difference is significant $(Z=4.354, \mathrm{p}<0.01)$ (Cohen, West, \& Aiken, 2014). Similarly, we split the data into high- and low-legal system completeness groups (observations above and below the median, respectively) and regressed cooperation performance on contractbased knowledge protection at both level. The results suggest that the effect of contract-based knowledge protection on cooperation performance is stronger in the high-legal system completeness group $(\beta=0.468, \mathrm{p}=0.000)$ than the low- legal system completeness group $(\beta=0.097, \mathrm{p}=0.349)$, and the difference is significant $(Z=9.185, \mathrm{p}<0.01)$. These additional analysis results are consistent with the previous test results, indicating that technological turbulence weakens the positive relationship between contract-based knowledge protection and cooperation performance, while legal system completeness strengthens this relationship, once again supporting $\mathrm{H} 3$ and $\mathrm{H} 4$.

\section{Discussion and implications}

Knowledge leakage is a salient risk in the inter-firm cooperation, and firm need to take appropriate approaches to prevent this risk (Jiang et al., 2013; Ryu, McCann, \& Reuer, 2018). Especially in developing economies, knowledge protection is much more important, because their legal system is still not well complete and the intellectual property protection is flawed (Roy \& Oliver, 2009; Sheng, Zhou, \& Lessassy, 2013; Wang et al., 2017). The findings suggest that technological turbulence and legal system completeness both have a significant and positive effect on contract-based knowledge protection. Meanwhile, technological turbulence weakens the positive relationship of contract-based knowledge protection and cooperation performance, while legal system completeness strengthens the same relationship. This study has the following theoretical contributions and managerial implications. 


\subsection{Theoretical contributions}

First, we advance the research on knowledge protection in inter-firm cooperation by exploring the specific role of contract-based knowledge protection in the context of China. Contract-based knowledge protection relies on the formulation and implementation of cooperation contracts to realize knowledge protection function in cooperative relationships (Norman, 2001; Manhart \& Thalmann, 2015; Veer et al., 2016). Despite some potential adverse effects on cooperation performance, such as signaling distrust and reducing communication and interaction (Wei et al., 2017), contract-based knowledge protection uses contracts to create mutually accepted clauses on knowledge protection (Mayer, 2006; Schubert, 2016) to serve as an internal formal rules to overcoming absence of effective IPRs in China (Eesley, Li, \& Yang, 2016). Thus, this paper proposed, in China, contract-based knowledge protection could play an even more critical role in reducing the risk and costs of knowledge leakage in cooperation and has a positive effect on cooperation performance. Our findings support this view and suggest there is a significant positive relationship between contract-based knowledge protection and cooperation performance. Although Norman (2001) has early proposed the important role of contract-based knowledge protection in inter-firm cooperation, there is little empirical research devoted to this knowledge protection measure in cooperation (e.g. Müller, 2010). Therefore, as far as we know, this paper is the earlier work to specifically analyze contract-based knowledge protection from the theoretical and empirical perspective, attributing to the research on knowledge protection in cooperation.

Second, this study extends the research on the antecedents of firm's knowledge protection in cooperation by exploring the direct effects of technological turbulence and legal system 
completeness on contract-based knowledge protection. While various and multilevel factors would influence firm's knowledge protection in cooperation, the existing literature has focused on firm's own characteristics and transaction factors (e.g. Neuhäusler, 2012; Norman, 2004; Yang et al., 2014). For example, Yang et al. (2014) found hostage arrangement enhances the level of knowledge protection, whereas the effect of reciprocal investment is not significant. These studies has provide some insight of what factors would influence firm's behavior of knowledge protection in cooperation, while the broader external environment factors have been overlooked.

As inter-firm exchanges are embedded in the broad task and institutional environments, organizational behaviors and actions is a function of external task and institutional environments (Wang et al., 2016; Sheng et al., 2018). Based on this view, our study suggested that task and institutional environments would influence firm's knowledge protection in cooperation, and found that technological turbulence and legal system completeness are positively associated with contract-based knowledge protection in the context of China. The former suggests that the uncertainty emerging from task environment, especially the technology, increases the value and importance of knowledge (Perri \& Andesson, 2014; Su et al., 2016), thus increasing the motivation and needs of contract-based knowledge protection; the latter suggests that the construction of much complete legal system improves the "rule of game" (North, 1990), thus reducing the cost of using contracts to protect private knowledge in cooperation. Therefore, our study improves the understanding of whether and what external environmental factors would affect firm's knowledge protection in cooperation, and complements the literature of research on the antecedents of knowledge protection in 
cooperation (e.g. Norman, 2004; Neuhäusler, 2012; Yang et al., 2014; Arora et al., 2016).

Third, this study extends the research on the contingent factors of the relationship between knowledge protection and performance outcomes by investigating the moderating effect of task and institutional environment factors. Existing literature offers the "double-edged sword" view regarding the role of knowledge protection in partnership, and has suggested that the effect of knowledge protection on performance outcomes may vary in different contexts (Jean et al., 2016; Wei et al., 2018). Based on TCE and institutional theory, although contract-based knowledge protection is aimed to use contracts to establish formal rules on reducing unwanted knowledge spillover and thus contribute to cooperation performance (Mayer, 2006; Schubert, 2016; Wei et al., 2018), it will hardly promote cooperation performance if the rules is inconsistent with the broader external environment, especially institutional environment (Eesley et al., 2016). We found that technological turbulence weakens the positive relationship between contract-based knowledge protection and cooperation performance, while legal system completeness enhances the same relationship. In other words, in the context of low level of technological turbulence or high level of legal system completeness, the positive relationship between contract-based knowledge protection and cooperation performance will be more significant.

Especially in developing economies, the role and effectiveness of intellectual property protection and contract governance are relatively limited due to the imperfect legal system (Sheng et al., 2013; Eesley et al., 2016). But with the gradual development of legal system, contract-based knowledge protection will get considerable improvement in the effectiveness, legitimacy and costs, and play a more positive role in enhancing cooperation performance. 
Moreover, considering the incomplete market structure in developing economies, when the technological turbulence is high, contract-based knowledge protection might have more negative effects on cooperation performance such as hindering knowledge exchange and signaling mistrust. Therefore, by investigating the different moderating effects of technological turbulence and legal system completeness on the relationship between contract-based knowledge protection and cooperation performance, this study helps to understand the complexity of environmental factors in developing economies and the boundary conditions under which knowledge protection plays a role in cooperation governance.

Overall, our study provides a holistic picture on the complex relationships between task and institutional environments and contract-based knowledge protection. We find technological turbulence and legal system completeness not only are positive associated with contract-based knowledge protection, but also moderate the relationship between contract-based knowledge protection and cooperation performance. Protecting firm's private knowledge in cooperation is important content of the governance of cooperative relationships (Jiang et al., 2013; Hoffmann et al., 2018; Gast et al., 2019). The existing literature on inter-firm relationship management emphasizes the alignment between relationship governance and external environments (Gray \& Handley, 2015; Wang et al., 2017; Yang et al., 2018; Sheng et al., 2018). Our findings provide an understanding of how firm's governance behavior on knowledge protection is shaped by external environments and is aligned with external environments to contribute to performance outcomes (Chang et al., 2015; Sheng et al., 2018). Moreover, this study reveals the complexity of the influence of institutional factor on firm's governance by simultaneously focusing on its direct effect and moderating effect on firm's governance decision on knowledge protection. As 
a result, this study also contributes to understanding "how institutions matter" (Peng et al., 2008; Peng et al., 2009; Peng, 2014).

\subsection{Managerial implications}

Owing to the underdeveloped legal system and market rules, there are many unfair competitions as well as simply copy and plagiarism in China, of which the US government accuses China in the latest US-China Trade War. Thus firms in China should attach importance to protecting their key knowledge resources. More importantly, the risk of knowledge leakage is not only caused by the theft of firm's direct competitors, but also the unintentional or intentional acquisition of sensitive knowledge by partners (Jiang et al., 2013; Ryu et al, 2018). Therefore, how to protect firm's knowledge in cooperation is one critical issue. In developed economies, firms often can rely on IPRs to protect their private knowledge (Sheng et al., 2013). However, IPRs involve a limited range of knowledge and are not sufficient to prevent knowledge leakage risks in China, where lacks a well-established formal intellectual property system (Eesley et al., 2016) and has greater challenges of technological turbulence from global competition (Jean et al., 2014; Wu et al., 2017). Therefore, managers need to adopt various knowledge protection measures in addition to IPRs in China. This paper suggested that contract-based knowledge protection might be a feasible alternative and would be conducive to improving cooperation performance in general.

Moreover, managers need to be aware of the complex and volatile external environment and have a tradeoff before making governance decisions about knowledge protection in China and other developing economies. Our study suggested that considering only unilateral environmental factors may lead to very limited conclusions. In developing economies, with the 
gradual improvement of legal system, the advantages of contract-based knowledge protection will gradually increase. Therefore, managers should realize the convenience conditions brought about by institution improvement, and adopt more formal governance mechanisms to regulate their partners. However, in the technological turbulent environment, managers often face a dilemma. On the one hand, high technological turbulence brings a higher demand for knowledge protection. On the other hand, high technological turbulence will magnify the negative impact of contract-based knowledge protection on cooperation performance. In this case, managers need to consider not only how to simply protect knowledge, but also how to align knowledge protection with the complex requirements of technological turbulence to achieve better cooperation performance. In other words, firm should maintain a suitable degree of knowledge protection in cooperation rather than infinitely increase it.

\subsection{Policy implications}

Many developing economies, such as China, are actively establishing and improving their own institutional system, and strive to create a good business environment (Zhou \& Poppo, 2010; Bai et al., 2016). However the latest US-China Trade War reminds us that there is still a huge gap between China and developed countries in intellectual property protection. Besides firms in China have always faced a highly uncertain task environment and a relatively underdeveloped institutional environment (Luo, 2005; Wu et al., 2017; Wang et al., 2019). Our study finds that with more complete legal system and lower technological turbulence, contract-based knowledge protection will be more effective in enhancing cooperation performance. Moreover, based the experiences of developed countries, the establishment of well complete laws and regulations and can encourage firm to innovate. Teece (1986) pointed out that an effective legal 
system is one of the important conditions for firms to obtain significant profits from innovation activities. Therefore, policy makers in China and other developing economies should strengthen their roles of formal institution suppliers and market service providers, and work together to improve task and institutional environments faced by firms. In the one hand, government could provide or establish the access for firm to sufficient resources and external capital market support, which help firm cope with the challenges of uncertain task environment. On the other hand, policy makers should strengthen the construction of intellectual property system and other legal laws and improve public awareness of the legal system, making firm's knowledge protection behaviors more acceptable and legitimate to network members. As a result, market participants will naturally take part in more regulated market activities and invest in innovation due to the improvement of institutional environment.

\subsection{Limitations and future research}

Our paper still has certain limitations that provide exploring directions for future research. First, this study focuses on contract-based knowledge protection measures. However, firms often synthetically use a variety of knowledge protection measures in cooperation. For example, in addition to IPRs and contract-based knowledge protection measures, firms can adopt a "gatekeeper" strategy, limit partner access to key employees, and regularly replace the cooperative interface employees to protect firm's sensitive knowledge. Therefore, future research can consider more knowledge protection instruments and the effects of different combinations of these protection instruments on performance outcomes.

Second, this study only investigates two macro environment factors (technological turbulence and legal system completeness), which may have impacts on firm's knowledge 
protection behaviors. In fact, other environment factors, such as competition intensity, legal service availability, might also influence the knowledge protection decision and the effects of knowledge protection on performance outcomes. Therefore, future research can further discuss the impacts of other more environmental factors on firm's knowledge protection.

Third, this study use a survey data which can better measure the constructs we want to explore, including firm's perceptions on the external environment, the using of contract-based knowledge protection, and the performance outcomes of cooperation. However, a richer source of data and long-term tracking study can provide more information and evidence for this research. Therefore, future research can use more diverse data sources and build panel data, which makes the research conclusions more reliable.

Finally, this study takes China as the research background and highlights the positive impact of contract-based knowledge protection on cooperation performance in China. Although the conclusions obtained in combination with specific situations are closer to management practices, the universality of research conclusions is relatively lower. Therefore, there is a demand for more research in other developing and developed economies to increase the applicability of research conclusions.

\section{References}

Aiken, L. S., \& West, S. G. (1991). Multiple regression: Testing and interpreting interactions. Newbury Park, CA: Sage.

Armstrong, J. S., \& Overton, T. S. (1977). Estimating nonresponse bias in mail surveys. Journal of Marketing Research, 14(3), 396-402.

Arora, A., Athreye, S., \& Huang, C. (2016). The paradox of openness revisited: Collaborative innovation and patenting by UK innovators. Research Policy, 45(7), 1352-1361.

Bai, X., Sheng, S., \& Li, J. J. (2016). Contract governance and buyer-supplier conflict: The moderating role of institutions. Journal of Operations Management, 41, 12-24. 
Baughn, C. C., Denekamp, J. G., Stevens, J. H., \& Osborn, R. N. (1997). Protecting intellectual capital in international alliances. Journal of World Business, 32(2), 103-117.

Candelin-Palmqvist, H., Sandberg, B., \& Mylly, U. M. (2012). Intellectual property rights in innovation management research: A review. Technovation, 32(9-10), 502-512.

Cao, Z., \& Lumineau, F. (2015). Revisiting the interplay between contractual and relational governance: A qualitative and meta-analytic investigation. Journal of Operations Management, 33, 15-42.

Chang, J., Bai, X., \& Li, J. J. (2015). The influence of institutional forces on international joint ventures' foreign parents' opportunism and relationship extendedness. Journal of International Marketing, 23(2), 73 93.

Chen, X., \& Wu, J. (2011). Do different guanxi types affect capability building differently? A contingency view. Industrial Marketing Management, 40(4), 581-592.

Child, J., Chung, L., \& Davies, H. (2003). The performance of cross-border units in China: A test of natural selection, strategic choice and contingency theories. Journal of International Business Studies, 34(3), 242254.

Christoffersen, J., Plenborg, T., \& Robson, M. J. (2014). Measures of strategic alliance performance, classified and assessed. International Business Review, 23(3), 479-489.

Claussen, J., Kretschmer, T., \& Stieglitz, N. (2014). Vertical scope, turbulence, and the benefits of commitment and flexibility. Management Science, 61(4), 915-929.

Cohen, P., West, S. G., \& Aiken, L. S. (2014). Applied multiple regression/correlation analysis for the behavioral sciences. Psychology Press.

de Leeuw, T., Lokshin, B., \& Duysters, G. (2014). Returns to alliance portfolio diversity: The relative effects of partner diversity on firm's innovative performance and productivity. Journal of Business Research, 67(9), 1839-1849.

Dess, G. G., \& Beard, D. W. (1984). Dimensions of organizational task environments. Administrative Science Quarterly, 52-73.

Eesley, C., Li, J. B., \& Yang, D. (2016). Does institutional change in universities influence high-tech entrepreneurship? Evidence from China’s Project 985. Organization Science, 27(2), 446-461.

Estrada, I., Faems, D., \& de Faria, P. (2016). Coopetition and product innovation performance: The role of internal knowledge sharing mechanisms and formal knowledge protection mechanisms. Industrial Marketing Management, 53, 56-65.

Frishammar, J., Ericsson, K., \& Patel, P. C. (2015). The dark side of knowledge transfer: Exploring knowledge leakage in joint $\mathrm{R} \& \mathrm{D}$ projects. Technovation, 41, 75-88.

Gast, J., Gundolf, K., Harms, R., \& Collado, E. M. (2019). Knowledge management and coopetition: How do cooperating competitors balance the needs to share and protect their knowledge?. Industrial Marketing Management, 77, 65-74.

Greif, A. (2005). Commitment, coercion, and markets: The nature and dynamics of institutions supporting exchange. In Handbook of new institutional economics (pp. 727-786). Springer, Boston, MA. 
Gu, F. F., Hung, K., \& Tse, D. K. (2008). When does guanxi matter? Issues of capitalization and its dark sides. Journal of Marketing, 72(4), 12-28.

Hagedoorn, J. (1993). Understanding the rationale of strategic technology partnering: Nterorganizational modes of cooperation and sectoral differences. Strategic Management Journal, 14(5), 371-385.

Hamilton, B. H., \& Nickerson, J. A. (2003). Correcting for endogeneity in strategic management research. Strategic Organization, 1(1), 51-78.

Hoffmann, W., Lavie, D., Reuer, J. J., \& Shipilov, A. (2018). The interplay of competition and cooperation. Strategic Management Journal, 39(12), 3033-3052.

Jaworski, B. J., \& Kohli, A. K. (1993). Market orientation: Antecedents and consequences. Journal of Marketing, 57(3), 53-70.

Jean, R. J. B., Sinkovics, R. R., \& Hiebaum, T. P. (2014). The effects of supplier involvement and knowledge protection on product innovation in customer-supplier relationships: A study of global automotive suppliers in China. Journal of Product Innovation Management, 31(1), 98-113.

Jiang, X., Bao, Y., Xie, Y., \& Gao, S. (2016). Partner trustworthiness, knowledge flow in strategic alliances, and firm competitiveness: A contingency perspective. Journal of Business Research, 69(2), 804-814.

Jiang, X., Li, M., Gao, S., Bao, Y., \& Jiang, F. (2013). Managing knowledge leakage in strategic alliances: The effects of trust and formal contracts. Industrial Marketing Management, 42(6), 983-991.

Ju, M., \& Gao, G. Y. (2017). Relational governance and control mechanisms of export ventures: an examination across relationship length. Journal of International Marketing, 25(2), 72-87.

Kale, P., Singh, H., \& Perlmutter, H. (2000). Learning and protection of proprietary assests in alliances: Bulding relational capital. Strategic Management Journal, 21(3), 217-237.

Kim, C., Lee, C., \& Kang, J. (2018). Determinants of firm's innovation-related external knowledge search strategy: The role of potential absorptive capacity and appropriability regime. International Journal of Innovation Management, 22(06), 1850044.

Kohli, A. K., \& Jaworski, B. J. (1990). Market orientation: The construct, research propositions, and managerial implications. Journal of Marketing, 54(2), 1-18

Lee, S. C., Chang, S. N., Liu, C. Y., \& Yang, J. (2007). The effect of knowledge protection, knowledge ambiguity, and relational capital on alliance performance. Knowledge and Process Management, 14(1), 5869.

Lee, Y., \& Cavusgil, S. T. (2006). Enhancing alliance performance: The effects of contractual-based versus relational-based governance. Journal of Business Research, 59 (8), 896-905.

Li, D., Eden, L., Hitt, M. A., \& Ireland, R. D. (2008). Friends, acquaintances, or strangers? Partner selection in R\&D alliances. Academy of Management Journal, 51(2), 315-334.

Li, Y., Xie, E., Teo, H. H., \& Peng, M. W. (2010). Formal control and social control in domestic and international buyer-supplier relationships. Journal of Operations Management, 28(4), 333-344.

Lindell, M. K., \& Whitney, D. J. (2001). Accounting for common method variance in cross-sectional research designs. Journal of Applied Psychology, 86(1), 114-121. 
Liu, Y., Luo, Y., \& Liu, T. (2009). Governing buyer-supplier relationships through transactional and relational mechanisms: Evidence from China. Journal of Operations Management, 27(4), 294-309.

Luo, Y. (2005). Transactional characteristics, institutional environment and joint venture contracts. Journal of International Business Studies, 36(2), 209-230.

Manhart, M., \& Thalmann, S. (2015). Protecting organizational knowledge: a structured literature review. Journal of Knowledge Management, 19(2), 190-211.

Mayer, K. J. (2006). Spillovers and governance: An analysis of knowledge and reputational spillovers in information technology. Academy of Management Journal, 49(1), 69-84.

Müller, D. (2010). Alliance coordination, dysfunctions, and the protection of idiosyncratic knowledge in strategic learning alliances. Working paper.

Musarra, G., Robson, M. J., \& Katsikeas, C. S. (2016). The influence of desire for control on monitoring decisions and performance outcomes in strategic alliances. Industrial Marketing Management, 55, 10-21.

Muthusamy, S. K., \& White, M. A. (2006). Does power sharing matter? The role of power and influence in alliance performance. Journal of Business Research, 59(7), 811-819.

Neuhäusler, P. (2012). The use of patents and informal appropriation mechanisms-Differences between sectors and among companies. Technovation, 32(12), 681-693.

Norman P. M. (2001). Are your secrets safe? Knowledge protection in strategic alliances. Business Horizons, 44(6), 51-60.

Norman, P. M. (2002). Protecting knowledge in strategic alliances: Resource and relational characteristics. The Journal of High Technology Management Research, 13(2), 177-202.

Norman, P. M. (2004). Knowledge acquisition, knowledge loss, and satisfaction in high technology alliances. Journal of Business Research, 57(6), 610-619.

North, C. D. (1990). Institutions, institutional change and economic performance. Cambridge, UK: Cambridge University Press.

North, C. D. (2005). Understanding the process of economic change. Princeton, NJ: Princeton University Press.

Olander, H., Hurmelinna-Laukkanen, P. I. A., \& Heilmann, P. I. A. (2011). Do SMEs benefit from HRMrelated knowledge protection in innovation management? International Journal of Innovation Management, 15(03), 593-616.

Olander, H., Vanhala, M., \& Hurmelinna-Laukkanen, P. (2014). Reasons for choosing mechanisms to protect knowledge and innovations. Management Decision, 52(2), 207-229.

Panico, C. (2017). Strategic interaction in alliances. Strategic Management Journal, 38(8), 1646-1667.

Paulraj, A., \& Chen, I. J. (2007). Environmental uncertainty and strategic supply management: a resource dependence perspective and performance implications. Journal of Supply Chain Management, 43(3), 29-42. Peng, M. W. (2003). Institutional transitions and strategic choices. Academy of Management Review, 28(2), 275-296.

Peng, M. W. (2014). New research directions in the institution-based view. In Multidisciplinary Insights from 
New AIB Fellows (pp. 59-78). Emerald Group Publishing Limited.

Peng, M. W., Sun, S. L., Pinkham, B., \& Chen, H. (2009). The institution-based view as a third leg for a strategy tripod. Academy of Management Perspectives, 23(3), 63-81.

Peng, M. W., Wang, D. Y., \& Jiang, Y. (2008). An institution-based view of international business strategy: A focus on emerging economies. Journal of International Business Studies, 39(5), 920-936.

Perri, A., \& Andersson, U. (2014). Knowledge outflows from foreign subsidiaries and the tension between knowledge creation and knowledge protection: Evidence from the semiconductor industry. International Business Review, 23(1), 63-75.

Qian, L., Yang, P., \& Li, Y. (2016). Does guanxi in china always produce value? The contingency effects of contract enforcement and market turbulence. Journal of Business \& Industrial Marketing, 31(7), 861-876.

Roy, J. P., \& Oliver, C. (2009). International joint venture partner selection: The role of the host-country legal environment. Journal of International Business Studies, 40(5), 779-801

Ryu, W., McCann, B. T., \& Reuer, J. J. (2018). Geographic co-location of partners and rivals: Implications for the design of R\&D alliances. Academy of Management Journal, 61(3), 945-965.

Samaha, S. A., Palmatier, R. W., \& Dant, R. P. (2011). Poisoning relationships: Perceived unfairness in channels of distribution. Journal of Marketing, 75(3), 99-117.

Schilke, O., \& Lumineau, F. (2018). The double-edged effect of contracts on alliance performance. Journal of Management, 44(7), 2827-2858.

Schubert, T. (2016). Infringement of intellectual property in innovation partnerships. $R \& D$ Management, 46(S2), 596-611.

Scott, W.R. (2001). Institutions and Organizations. USA: Sage Publications.

Sheng, S., Zhou, K. Z., \& Lessassy, L. (2013). NPD speed vs. innovativeness: The contingent impact of institutional and market environments. Journal of Business Research, 66(11), 2355-2362.

Sheng, S., Zhou, K. Z., \& Li, J. J. (2011). The effects of business and political ties on firm performance: Evidence from China. Journal of Marketing, 75(1), 1-15.

Sheng, S., Zhou, K. Z., Li, J. J., \& Guo, Z. (2018). Institutions and opportunism in buyer-supplier exchanges: the moderated mediating effects of contractual and relational governance. Journal of the Academy of Marketing Science, 46(6), 1014-1031.

Shou, Z., Zheng, X. V., \& Zhu, W. (2016). Contract ineffectiveness in emerging markets: An institutional theory perspective. Journal of Operations Management, 46, 38-54.

Shu, C., Jin, J. L., \& Zhou, K. Z. (2017). A contingent view of partner coopetition in international joint ventures. Journal of International Marketing, 25(3), 42-60.

Slater, S. F., \& Narver, J. C. (1994). Does competitive environment moderate the market orientationperformance relationship? Journal of Marketing, 58(1), 46-55.

Srivastava, P., \& Frankwick, G. L. (2011). Environment, management attitude, and organizational learning in alliances. Management Decision, 49(1), 156-166.

Stefan, I., \& Bengtsson, L. (2017). Unravelling appropriability mechanisms and openness depth effects on 
firm performance across stages in the innovation process. Technological Forecasting and Social Change, $120,252-260$.

Su, Z., Peng, M. W., \& Xie, E. (2016). A strategy tripod perspective on knowledge creation capability. British Journal of Management, 27(1), 58-76.

Sun, F., Hong, J., Ma, X., \& Wang, C. (2017). Subnational institutions and open innovation: evidence from China. Management Decision, 55(9), 1942-1955.

Teece, D. J. (1986). Profiting from technological innovation: Implications for integration, collaboration, licensing and public policy. Research Policy, 15(6), 285-305.

Terawatanavong, C., Whitwell, G. J., Widing, R. E., \& O'Cass, A. (2011). Technological turbulence, supplier market orientation, and buyer satisfaction. Journal of Business Research, 64(8), 911-918.

Trkman, P., \& McCormack, K. (2009). Supply chain risk in turbulent environments-A conceptual model for managing supply chain network risk. International Journal of Production Economics, 119(2), 247-258. Veer, T., Lorenz, A., \& Blind, K. (2016). How open is too open? The mitigating role of appropriation mechanisms in R\&D cooperation settings. R\&D Management, 46(S3), 1113-1128.

Villena, V. H., Revilla, E., \& Choi, T. Y. (2011). The dark side of buyer-supplier relationships: A social capital perspective. Journal of Operations Management, 29(6), 561-576.

Wadhwa A., Bodas Freitas I. M., Sarkar M. B. (2017). The paradox of openness and value protection strategies: Effect of extramural R\&D on innovative performance. Organization Science, 28(5), 873-893.

Walter, J., Lechner, C., \& Kellermanns, F. W. (2008). Disentangling alliance management processes: decision making, politicality, and alliance performance. Journal of Management Studies, 45(3), 530-560.

Wang, J. J., Li, J. J., \& Chang, J. (2016). Product co-development in an emerging market: The role of buyersupplier compatibility and institutional environment. Journal of Operations Management, 46, 69-83.

Wang, L., Jin, J. L., \& Zhou, K. Z. (2019). Institutional forces and customer participation in new product development: A Yin-Yang perspective. Industrial Marketing Management. In Press.

Wang, L., Zhang, M., \& Li, X. (2017). Trust and knowledge creation: The moderating effects of legal inadequacy. Industrial Management \& Data Systems, 117(10), 2194-2209.

Wang, M., Zhang, Q., Wang, Y., \& Sheng, S. (2016). Governing local supplier opportunism in China: Moderating role of institutional forces. Journal of Operations Management, 46, 84-94.

Wei, Z., Du, Z., \& Bao, Y. (2018). Outsourcer Knowledge Protection, Psychological Contract Schema, and Project Performance: A Vendor's Perspective. IEEE Transactions on Engineering Management, 65(1), 128140.

Wei, Z., Shen, H., Zhou, K. Z., \& Li, J. J. (2017). How does environmental corporate social responsibility matter in a dysfunctional institutional environment? Evidence from China. Journal of Business Ethics, 140(2), 209-223.

White III, G. O., Boddewyn, J. J., \& Galang, R. M. N. (2015). Legal system contingencies as determinants of political tie intensity by wholly owned foreign subsidiaries: Insights from the Philippines. Journal of World Business, 50(2), 342-356. 
Williams, L. J., Hartman, N., \& Cavazotte, F. (2010). Method variance and marker variables: A review and comprehensive CFA marker technique. Organizational Research Methods, 13(3), 477-514.

Wu, L., Liu, H., \& Zhang, J. (2017). Bricolage effects on new-product development speed and creativity: The moderating role of technological turbulence. Journal of Business Research, 70, 127-135.

Yang, D., Sheng, S., Wu, S., \& Zhou, K. Z. (2018). Suppressing partner opportunism in emerging markets: Contextualizing institutional forces in supply chain management. Journal of Business Research, 90, 1-13.

Yang, S. M., Fang, S. C., Fang, S. R., \& Chou, C. H. (2014). Knowledge exchange and knowledge protection in interorganizational learning: the ambidexterity perspective. Industrial Marketing Management, 43(2), 346358.

Yeung, K., Lee, P. K. C., Yeung, A. C. L., \& Cheng, T. C. E. (2013). Supplier partnership and cost performance: the moderating roles of specific investments and environmental uncertainty. International Journal of Production Economics, 144(2), 546-559.

Zhang, C., Li, J. J., \& Huang, Y. (2017). Sustaining relationships after opportunism and misunderstanding: the role of formalization and socialization. Marketing Letters, 28(2), 305-319.

Zhou, K. Z. (2006). Innovation, imitation, and new product performance: The case of China. Industrial Marketing Management, 35(3), 394-402.

Zhou, K. Z., \& Poppo, L. (2010). Exchange hazards, relational reliability, and contracts in China: The contingent role of legal enforceability. Journal of International Business Studies, 41(5), 861-881.

Zhou, K. Z., Su, C., Yeung, A., \& Viswanathan, S. (2016). Supply chain management in emerging markets. Journal of Operations Management, 46, 1-4. 


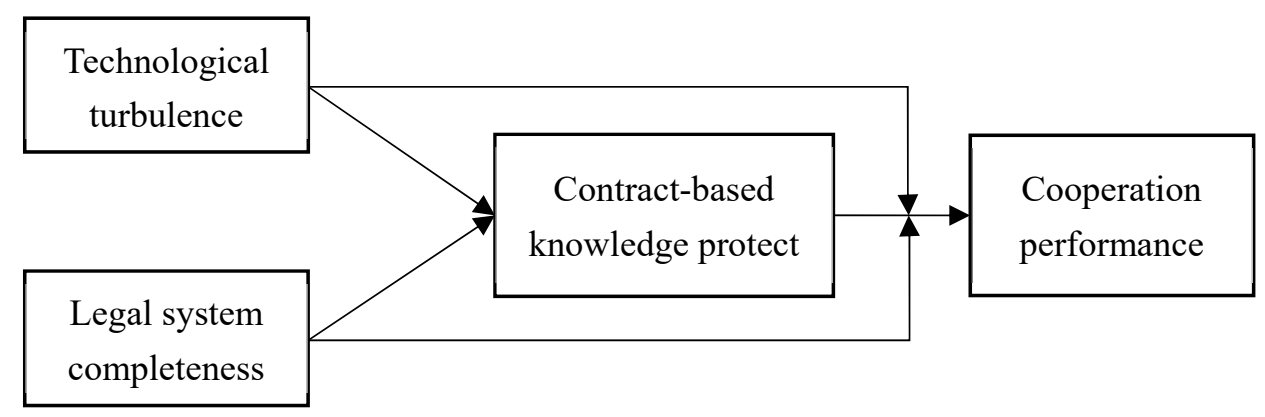

Fig. 1. Conceptual model.
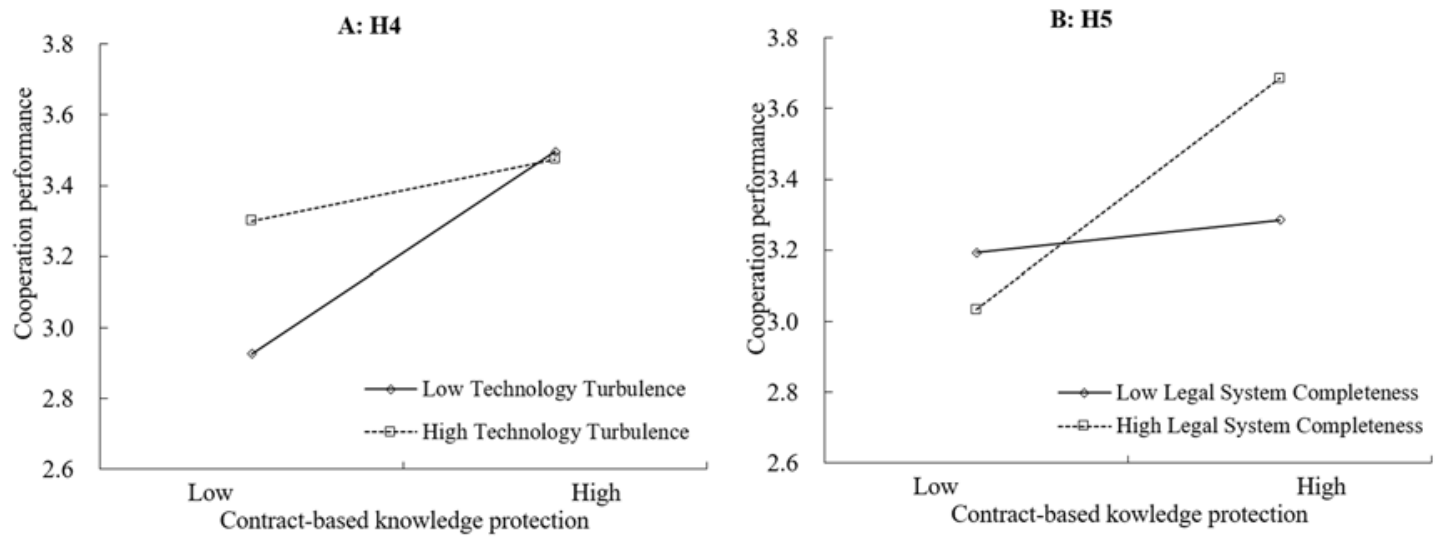

Fig. 2. Moderating effects of technological turbulence and legal system completeness. 


\section{Table 1}

Descriptive statistics

\begin{tabular}{|c|c|c|c|c|c|c|c|}
\hline Classification & Item & Number & $\begin{array}{c}\text { Percentage } \\
(\%)\end{array}$ & Classification & Item & Number & $\begin{array}{c}\text { Percentage } \\
(\%)\end{array}$ \\
\hline Firm size & $\leqslant 50$ & 48 & $21.1 \%$ & Location & the Bo Hai Coastal Region & 43 & $18.9 \%$ \\
\hline (number of & $51-200$ & 71 & $31.3 \%$ & & the Yangtze River Delta & 18 & $7.9 \%$ \\
\hline \multirow[t]{3}{*}{ employees) } & $201-500$ & 37 & $16.3 \%$ & & the Pearl River Delta & 76 & $33.5 \%$ \\
\hline & $501-1000$ & 24 & $10.6 \%$ & & the central and western regions & 90 & $39.7 \%$ \\
\hline & $>1000$ & 47 & $20.7 \%$ & Ownership & State-owned enterprises & 62 & $27.3 \%$ \\
\hline Firm age & $\leqslant 5$ & 10 & $4.4 \%$ & & private enterprises & 146 & $64.3 \%$ \\
\hline \multirow[t]{4}{*}{ (years) } & $6-10$ & 56 & $24.7 \%$ & & foreign-owned/joint venture enterprises & 19 & $8.4 \%$ \\
\hline & $10-15$ & 61 & $26.9 \%$ & Cooperation & $\leqslant 2$ & 32 & $14.1 \%$ \\
\hline & $16-20$ & 48 & $21.1 \%$ & duration & $3-5$ & 80 & $30.8 \%$ \\
\hline & $>20$ & 52 & $22.9 \%$ & (years) & $6-10$ & 85 & $37.5 \%$ \\
\hline \multirow[t]{5}{*}{ Industry } & Machinery manufacturing & 78 & $34.4 \%$ & & $>10$ & 69 & $17.6 \%$ \\
\hline & Electrommunication & 64 & $28.2 \%$ & Partner type & Supplier & 83 & $38.1 \%$ \\
\hline & Metal and chemistry goods & 45 & $19.8 \%$ & & Customer & 107 & $49.1 \%$ \\
\hline & others & 40 & $17.6 \%$ & & $\mathrm{R} \& \mathrm{D}$ & 37 & $23.8 \%$ \\
\hline & & & & & Total & 227 & $100 \%$ \\
\hline
\end{tabular}


Table 2

Descriptive statistics and correlations of the constructs.

\begin{tabular}{|c|c|c|c|c|c|c|c|c|c|c|c|c|}
\hline & & 1 & 2 & 3 & 4 & 5 & 6 & 7 & 8 & 9 & 10 & 11 \\
\hline 1 & Firm age & N/A & $\begin{array}{l}0.507^{*} \\
*\end{array}$ & $\begin{array}{l}0.588^{*} \\
*\end{array}$ & $0.140^{*}$ & $-0.131^{*}$ & -0.016 & -0.076 & -0.115 & 0.069 & 0.018 & 0.004 \\
\hline 2 & $\begin{array}{l}\text { Firm } \\
\text { size }\end{array}$ & $\begin{array}{l}0.513^{*} \\
*\end{array}$ & N/A & $\begin{array}{l}0.368^{*} \\
*\end{array}$ & 0.050 & -0.081 & 0.040 & -0.060 & -0.097 & -0.031 & 0.022 & -0.033 \\
\hline 3 & Duration & $\begin{array}{l}0.593^{*} \\
*\end{array}$ & $\begin{array}{l}0.376^{*} \\
*\end{array}$ & N/A & 0.082 & -0.130 & 0.039 & 0.055 & -0.130 & -0.038 & -0.031 & 0.019 \\
\hline 4 & MM & $0.150^{*}$ & 0.061 & 0.093 & N/A & -0.471 & $\begin{array}{l}- \\
0.377^{* *}\end{array}$ & 0.085 & 0.091 & 0.049 & 0.029 & 0.031 \\
\hline 5 & EM & -0.117 & -0.068 & -0.116 & $\begin{array}{l}- \\
0.453^{* *}\end{array}$ & N/A & $\begin{array}{l}- \\
0.328^{* *}\end{array}$ & 0.075 & $\begin{array}{l}0.189^{*} \\
*\end{array}$ & -0.078 & -0.030 & 0.101 \\
\hline 6 & $\mathrm{MC}$ & -0.004 & 0.052 & 0.051 & $\begin{array}{l}- \\
0.360^{* *}\end{array}$ & $\begin{array}{l}- \\
0.312^{* *}\end{array}$ & N/A & -0.095 & $\begin{array}{l}- \\
0.141^{*}\end{array}$ & 0.037 & 0.070 & -0.030 \\
\hline 7 & TSI & -0.063 & -0.047 & 0.066 & 0.096 & 0.086 & -0.082 & 0.835 & $\begin{array}{l}0.204^{*} \\
*\end{array}$ & 0.080 & $\begin{array}{l}0.257^{*} \\
*\end{array}$ & $\begin{array}{l}0.345^{*} \\
*\end{array}$ \\
\hline 8 & $\mathrm{TU}$ & -0.102 & -0.084 & -0.116 & 0.102 & $0.199^{* *}$ & -0.127 & $\begin{array}{l}0.214^{*} \\
*\end{array}$ & 0.731 & $0.145^{*}$ & $\begin{array}{l}0.233^{*} \\
*\end{array}$ & $\begin{array}{l}0.220^{*} \\
*\end{array}$ \\
\hline 9 & LSC & 0.080 & -0.019 & -0.026 & 0.060 & -0.065 & 0.049 & 0.091 & $0.155^{*}$ & 0.957 & $\begin{array}{l}0.212^{*} \\
*\end{array}$ & 0.102 \\
\hline $\begin{array}{l}1 \\
0\end{array}$ & CKP & 0.030 & 0.034 & -0.019 & 0.041 & -0.018 & 0.081 & $\begin{array}{l}0.266^{*} \\
*\end{array}$ & $\begin{array}{l}0.242^{*} \\
*\end{array}$ & $\begin{array}{l}0.221^{*} \\
*\end{array}$ & 0.890 & $\begin{array}{l}0.364^{*} \\
*\end{array}$ \\
\hline 11 & $\mathrm{CP}$ & 0.018 & -0.048 & 0.029 & 0.113 & 0.026 & -0.025 & $\begin{array}{l}0.293^{*} \\
*\end{array}$ & $\begin{array}{l}0.244^{*} \\
*\end{array}$ & $\begin{array}{l}0.195^{*} \\
*\end{array}$ & $\begin{array}{l}0.399^{*} \\
*\end{array}$ & 0.852 \\
\hline 1 & GI(MV) & 0.028 & 0.019 & 0.012 & -0.003 & -0.014 & -0.064 & 0.014 & -0.018 & -0.052 & 0.030 & 0.050 \\
\hline 2 & Mean & 2.676 & 5.516 & 1.724 & 0.340 & 0.280 & 0.200 & 3.216 & 3.761 & 3.135 & 3.655 & 3.809 \\
\hline & S.D & 0.617 & 1.848 & 0.778 & 0.476 & 0.451 & 0.400 & 0.860 & 0.786 & 0.793 & 0.664 & 0.647 \\
\hline
\end{tabular}

$\mathrm{N}=227$. Zero-order correlations are below the diagonal; adjusted correlations for potential common method bias are above the diagonal; the values of the diagonal (in italics) are the square root of the AVE (average variance extracted) values.

Note:

MM (machinery manufacturing), EM (electrommunication), MC (metal and chemistry goods), TSI (transactionspecial investment), TU (technological turbulence), LSC (legal system completeness), CKP (contract-based knowledge protection), CP (cooperation performance), GI (government intervention). ${ }^{*} \mathrm{p}<0.05, * * \mathrm{p}<0.01$. 
Table 3

Regression results.

\begin{tabular}{|c|c|c|c|c|c|c|c|c|c|c|c|c|c|c|c|c|c|}
\hline & & \multicolumn{4}{|c|}{ Contract-based knowledge protection } & \multicolumn{12}{|c|}{ Cooperation performance } \\
\hline & & \multicolumn{2}{|c|}{ Model 1} & \multicolumn{2}{|c|}{ Model 2} & \multicolumn{2}{|c|}{ Model 3} & \multicolumn{2}{|c|}{ Model 4} & \multicolumn{2}{|c|}{ Model 5} & \multicolumn{2}{|c|}{ Model 6} & \multicolumn{2}{|c|}{ Model 7} & \multicolumn{2}{|c|}{ Model 8} \\
\hline & & $\beta$ & $\mathrm{t}$ & $\beta$ & $\mathrm{t}$ & $\beta$ & $\mathrm{t}$ & $\beta$ & $\mathrm{t}$ & $\beta$ & $\mathrm{t}$ & $\beta$ & $\mathrm{t}$ & $\beta$ & $\mathrm{t}$ & $\beta$ & $\mathrm{t}$ \\
\hline \multicolumn{18}{|c|}{ Control variable } \\
\hline Firm age & & 0.093 & 1.059 & 0.068 & 0.787 & 0.069 & 0.092 & 0.045 & 0.091 & 0.024 & 0.087 & 0.014 & 0.084 & 0.024 & 0.087 & 0.020 & 0.084 \\
\hline Firm size & & 0.034 & 0.448 & 0.05 & 0.682 & -0.026 & 0.026 & -0.021 & 0.026 & -0.026 & 0.025 & -0.016 & 0.024 & -0.026 & 0.025 & -0.017 & 0.024 \\
\hline Duration & & -0.116 & -1.432 & -0.078 & -0.984 & -0.007 & 0.067 & 0.021 & 0.066 & 0.041 & 0.063 & 0.052 & 0.061 & 0.041 & 0.063 & 0.052 & 0.061 \\
\hline Industry_MM & & 0.081 & 0.892 & 0.019 & 0.216 & $0.225^{\dagger}$ & 0.123 & 0.152 & 0.123 & 0.144 & 0.117 & 0.136 & 0.113 & 0.144 & 0.117 & 0.126 & 0.113 \\
\hline Industry_EC & & 0.041 & 0.459 & -0.017 & -0.192 & 0.156 & 0.127 & 0.085 & 0.128 & 0.092 & 0.122 & 0.091 & 0.118 & 0.092 & 0.122 & 0.090 & 0.118 \\
\hline Industry_MC & & $0.151^{\dagger}$ & 1.79 & 0.119 & 1.457 & 0.155 & 0.136 & 0.111 & 0.133 & 0.051 & 0.128 & 0.088 & 0.123 & 0.051 & 0.128 & 0.085 & 0.123 \\
\hline TSI & & $0.282^{* * *}$ & 4.265 & $0.233^{* * *}$ & 3.566 & $0.208^{* * *}$ & 0.050 & $0.176^{* * *}$ & 0.049 & $0.122^{*}$ & 0.048 & $0.116^{*}$ & 0.047 & $0.122^{*}$ & 0.048 & $0.122^{* *}$ & 0.047 \\
\hline \multicolumn{18}{|l|}{ Direct effects } \\
\hline $\mathrm{TU}$ & $\mathrm{H} 1$ & & & $0.186^{* *}$ & 2.748 & & & $0.132^{*}$ & 0.056 & 0.085 & 0.054 & $0.112^{*}$ & 0.053 & $0.139^{* *}$ & 0.053 & $0.185^{* * *}$ & 0.053 \\
\hline LSC & $\mathrm{H} 2$ & & & $0.156^{*}$ & 2.422 & & & $0.113^{*}$ & 0.053 & 0.074 & 0.051 & 0.076 & 0.049 & $0.121^{*}$ & 0.050 & $0.110^{*}$ & 0.049 \\
\hline CKP & $\mathrm{H} 3$ & & & & & & & & & $0.300^{* * *}$ & 0.063 & $0.280^{* * *}$ & 0.061 & $0.300^{* * *}$ & 0.063 & $0.268^{* * *}$ & 0.062 \\
\hline \multicolumn{18}{|c|}{ Moderating effects } \\
\hline CKP*TU & $\mathrm{H} 4$ & & & & & & & & & & & $-0.189^{* *}$ & 0.072 & & & $-0.197^{* *}$ & 0.072 \\
\hline CKP*LSC & H5 & & & & & & & & & & & $0.266^{* * *}$ & 0.068 & & & $0.270^{* *}$ & 0.074 \\
\hline $\mathrm{R}^{2}$ & & 0.096 & & 0.157 & & 0.105 & & 0.152 & & 0.231 & & 0.297 & & 0.231 & & 0.294 & \\
\hline$\Delta \mathrm{R}^{2}$ & & & & $0.061^{* * *}$ & & & & $0.047^{* * *}$ & & $0.080^{* * *}$ & & $0.065^{* *}$ & & & & $0.063^{* * *}$ & \\
\hline $\mathrm{F}$ & & $3.324^{* *}$ & & $4.505^{* * *}$ & & $3.657^{* * *}$ & & $4.311^{* * *}$ & & $6.500^{* * *}$ & & $7.526^{* * *}$ & & $6.500^{* * *}$ & & $7.437^{* * *}$ & \\
\hline Max VIF & & 2.006 & & 2.098 & & 2.006 & & 2.098 & & 2.098 & & 2.104 & & 2.098 & & 2.101 & \\
\hline
\end{tabular}

Note: $\mathrm{N}=227 ; \dagger \mathrm{p}<0.1,{ }^{*} \mathrm{p}<0.05, * * \mathrm{p}<0.01, * * * \mathrm{p}<0.001$. 


\section{Appendix A. Measures}

\begin{tabular}{|c|c|c|}
\hline Construct and sources & Description & $\begin{array}{l}\text { Factor } \\
\text { loadings }\end{array}$ \\
\hline Technological turbulence & In the past three years, & \\
\hline (Terawatanavong, 2011) & In our industry, technology changes and develops rapidly. & 0.722 \\
\hline$\alpha=0.760$ & Technological changes in the industry bring various new & 0.839 \\
\hline $\mathrm{AVE}=0.533$ & opportunities. & \\
\hline $\mathrm{CR}=0.771$ & $\begin{array}{l}\text { Many product innovations in the industry are realized } \\
\text { through technological breakthroughs. }\end{array}$ & 0.612 \\
\hline Legal system completeness & Currently in our country, & \\
\hline (Luo, 2005; White et al., 2015) & The legal system is well complete and perfect. & 0.851 \\
\hline$\alpha=0.916$ & Laws and regulations such as property laws, contract laws & 0.931 \\
\hline $\mathrm{AVE}=0.689$ & and intellectual property laws are well complete. & \\
\hline \multirow[t]{3}{*}{$\mathrm{CR}=0.916$} & $\begin{array}{l}\text { The legal system on protecting intellectual property rights } \\
\text { have been well complete }\end{array}$ & 0.872 \\
\hline & $\begin{array}{l}\text { The laws and regulations governing business conflicts and } \\
\text { disputes are well complete. }\end{array}$ & 0.755 \\
\hline & $\begin{array}{l}\text { The law on deal with cooperation issues between firms is } \\
\text { well complete. }\end{array}$ & 0.722 \\
\hline Contract-based knowledge & In the cooperation, & \\
\hline $\begin{array}{l}\text { protection } \\
\text { (Norman, } 2001 \text { and Müller, 2010) }\end{array}$ & $\begin{array}{l}\text { We clearly defined the scope of knowledge exchange } \\
\text { between the parties in the contract. }\end{array}$ & 0.735 \\
\hline$\alpha=0.792$ & We clearly stipulated in the contract how to protect our & 0.770 \\
\hline $\mathrm{AVE}=0.561$ & knowledge. & \\
\hline $\mathrm{CR}=0.794$ & $\begin{array}{l}\text { We established a highly formalized communication } \\
\text { channel between the two parties by the contract. }\end{array}$ & 0.743 \\
\hline Cooperation performance & In the cooperation, & \\
\hline $\begin{array}{l}\text { (Musarra et al., } 2016 \text { and Schilke } \\
\text { and Lumineau, 2018) }\end{array}$ & $\begin{array}{l}\text { We and our partners make the effective utilization of the } \\
\text { resources in cooperation }\end{array}$ & 0.829 \\
\hline$\alpha=0.887$ & We and our partners effectively convert inputs into outputs & 0.910 \\
\hline $\mathrm{AVE}=0.725$ & We have successfully achieved our cooperation goals with & 0.813 \\
\hline $\mathrm{CR}=0.888$ & our partners. & \\
\hline Transaction-specific investments & In order to better cooperate with this partner, & \\
\hline $\begin{array}{l}\text { (Zhou \& Poppo, 2010) } \\
\alpha=0.901\end{array}$ & $\begin{array}{l}\text { We invested heavily in the purchase of specialized } \\
\text { equipment. }\end{array}$ & 0.790 \\
\hline \multirow{4}{*}{$\begin{array}{l}\mathrm{AVE}=0.698 \\
\mathrm{CR}=0.902\end{array}$} & We have made great adjustments to the production & 0.893 \\
\hline & process. & \\
\hline & We have made major changes to our products. & 0.864 \\
\hline & $\begin{array}{l}\text { We have adjusted the organizational structure and } \\
\text { management system. }\end{array}$ & 0.790 \\
\hline
\end{tabular}

